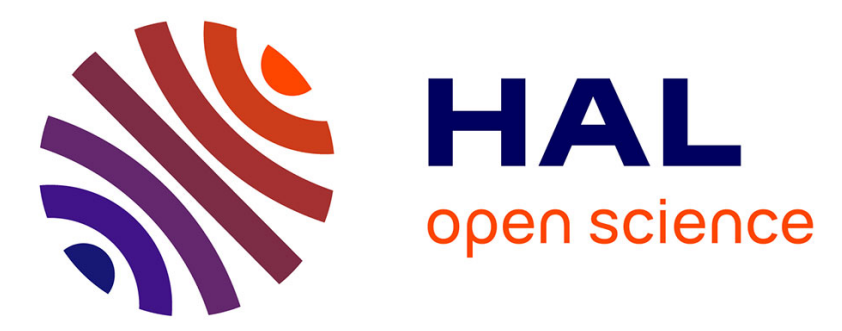

\title{
High efficiency and informativeness of a set of SNP molecular markers in Tunisian local grapevines discrimination
}

Leila L. Riahi, Besma B. Ayari, Nejia N. Zoghlami, Alexis Dereeper, Valerie V. Laucou, Ahmed A. Mliki, Patrice P. This

\section{To cite this version:}

Leila L. Riahi, Besma B. Ayari, Nejia N. Zoghlami, Alexis Dereeper, Valerie V. Laucou, et al.. High efficiency and informativeness of a set of SNP molecular markers in Tunisian local grapevines discrimination. Biochemical Systematics and Ecology, 2013, 51, pp.175-183. 10.1016/j.bse.2013.08.021 . hal-01004767

\section{HAL Id: hal-01004767 \\ https://hal.science/hal-01004767}

Submitted on 29 May 2020

HAL is a multi-disciplinary open access archive for the deposit and dissemination of scientific research documents, whether they are published or not. The documents may come from teaching and research institutions in France or abroad, or from public or private research centers.
L'archive ouverte pluridisciplinaire HAL, est destinée au dépôt et à la diffusion de documents scientifiques de niveau recherche, publiés ou non, émanant des établissements d'enseignement et de recherche français ou étrangers, des laboratoires publics ou privés. 


\title{
High efficiency and informativeness of a set of SNP molecular markers in Tunisian local grapevines discrimination
}

\author{
Leila Riahi $^{\mathrm{a}, *}$, Besma Ayari ${ }^{\mathrm{b}}$, Nejia Zoghlami ${ }^{\mathrm{a}}$, Alexis Dereeper ${ }^{\mathrm{c}}$, \\ Valérie Laucou $^{\mathrm{d}}$, Ahmed Mliki ${ }^{\mathrm{a}}$, Patrice This ${ }^{\mathrm{d}}$ \\ a Laboratoire de Physiologie Moléculaire des Plantes, Centre de Biotechnologie Borj Cedria, B.P. 901, Hammam-Lif 2050, Tunisia \\ ${ }^{\mathrm{b}}$ Laboratoire de Biochimie et de Biologie Moléculaire, Faculté des Sciences de Bizerte, Zarzouna, 7021 Bizerte, Tunisia \\ ${ }^{\mathrm{C}}$ UMR RPB (IRD-UM2-CIRAD) Résistance des Plantes aux Bioagresseurs, IRD, 911, avenue Agropolis, BP 64501, 34394 Montpellier, France \\ ${ }^{\mathrm{d}}$ Equipe DAVEM, UMR AGAP 1334, INRA SupAgro, 2 place Pierre Viala, 34060 Montpellier, France
}

\section{A R T I C L E I N F O}

\section{Article history:}

Received 14 May 2013

Accepted 10 August 2013

Available online

\section{Keywords:}

Vitis vinifera $\mathrm{L}$.

SNPs

Polymorphism

Genetic structure

Discrimination

Tunisia

\begin{abstract}
A B S T R A C T
The sequencing of $3.726 \mathrm{~kb}$ of grape DNA genome among 44 local Tunisian grapevine accessions has allowed the detection of 73 SNPs which gave an average of one SNP every $51 \mathrm{bp}$. Based on this set of SNP molecular markers, the analyzed samples exhibited important levels of genetic polymorphism which confirms previous reports and highlights the utility of Tunisian grapevine germplasm as a reservoir of genetic polymorphism which can be exploited for breeding and conservation programs of the species. Moreover, these results showed the efficiency of SNP molecular marker in genetic structure analysis. Thus, our results suggest two probable origins for Tunisian cultivars which confirm previous molecular studies and historical data. The set of 73 SNPs allowed the unambiguous discrimination of all the studied accessions. Our analysis showed that a set of 27 SNPs were able to identify all the analyzed cultivars. On the other hand, a set of 22 SNPs is shown sufficient to discriminate all the wild accessions. Those two SNP sets could be taken into consideration in further studies concerning cultivars identification and wild accessions discrimination of the species Vitis vinifera $\mathrm{L}$.
\end{abstract}

(c) 2013 Elsevier Ltd. All rights reserved.

\section{Introduction}

Single nucleotide polymorphisms (SNPs), defined as any single base substitution/indel in the genome of an individual (Primmer et al., 2002), are among the current generation of molecular markers and have gained much interest in recent years (Dong et al., 2010). SNPs are the most common class for the detection of the smallest unit of genetic variation among individuals within a species and are usually bi-allelic variations between individuals that occur in/or between genes (Rafalski, 2002).

Due to their higher availability and stability when compared to simple sequence repeats (SSRs), SNPs are the most abundant type of DNA sequence polymorphisms which make them useful markers for genetic studies of plants such as construction of genetic maps, the assessment of genetic diversity, the detection of genotype/phenotype associations or marker-assisted breeding (Lijavetzky et al., 2007). Furthermore, SNP molecular markers have been used successfully to fingerprint varieties of various plant species (Ganal et al., 2009) like olive (Reale et al., 2006), rice (Shirasawa et al., 2006), citrus (Jiang et al., 2010), eggplant (Barchi et al., 2011) and Sweet Cherry cultivars (Ganopoulos et al., 2013).

\footnotetext{
* Corresponding author.

E-mail address: riahi.0311@yahoo.fr (L. Riahi).
} 
Table 1

List and characteristics of the studied grapevine accessions.

\begin{tabular}{|c|c|c|c|}
\hline Accession name & Code in the manuscript & Status & Collection of origin \\
\hline Beldi Baddar & CT1 & Cultivated & CBBC \\
\hline Hencha 1 & $\mathrm{CT} 2$ & Cultivated & $\mathrm{CBBC}$ \\
\hline Balta 1 & СТ3 & Cultivated & CBBC \\
\hline Sakasly Djerba & CT4 & Cultivated & CBBC \\
\hline Razaki & CT5 & Cultivated & $\mathrm{CBBC}$ \\
\hline Amokrane & CT6 & Cultivated & CBBC \\
\hline Razegui & CT7 & Cultivated & $\mathrm{CBBC}$ \\
\hline Medina Gabès & CT8 & Cultivated & $\mathrm{CBBC}$ \\
\hline Akhal Mguergueb & CT9 & Cultivated & CBBC \\
\hline Asli Dar Slimane & CT10 & Cultivated & CBBC \\
\hline Blanc 3 & CT11 & Cultivated & CBBC \\
\hline Tounsi Djerba & CT12 & Cultivated & $\mathrm{CBBC}$ \\
\hline El Biodh & CT13 & Cultivated & $\mathrm{CBBC}$ \\
\hline Bezzoul el Khadem Rafraf & CT14 & Cultivated & CBBC \\
\hline Muscat d'Alexandrie & CT15 & Cultivated & CBBC \\
\hline Khedhiri 2 & CT16 & Cultivated & CBBC \\
\hline Khalt Bouchemma Gabès & CT17 & Cultivated & CBBC \\
\hline Marsaoui & CT18 & Cultivated & $\mathrm{CBBC}$ \\
\hline Bidh Hamem Rafraf & CT19 & Cultivated & $\mathrm{CBBC}$ \\
\hline Blanc 1 & СT20 & Cultivated & CBBC \\
\hline Khalt & CT21 & Cultivated & CBBC \\
\hline Jerbi Déguache & CT22 & Cultivated & CBBC \\
\hline Djebba & WT1 & Wild & Prospection Tunisia \\
\hline El berka & WT2 & Wild & Prospection Tunisia \\
\hline Feidja 2 & WT3 & Wild & Prospection Tunisia \\
\hline Khédhayria & WT4 & Wild & Prospection Tunisia \\
\hline Fernana & WT5 & Wild & Prospection Tunisia \\
\hline Cap Serrat & WT6 & Wild & Prospection Tunisia \\
\hline Zouaraa & WT7 & Wild & Prospection Tunisia \\
\hline Tebaba & WT8 & Wild & Prospection Tunisia \\
\hline Lambrusque Ain Draham 2 & WT9 & Wild & Vassal Collection \\
\hline Saniat Abdallah & WT10 & Wild & Prospection Tunisia \\
\hline Bellif B4 & WT11 & Wild & Prospection Tunisia \\
\hline Lambrusque Ain Draham 1 & WT12 & Wild & Vassal Collection \\
\hline Feidja 1 & WT13 & Wild & Prospection Tunisia \\
\hline Houamdia & WT14 & Wild & Prospection Tunisia \\
\hline Lambrusque Cap Negre 2 & WT15 & Wild & Vassal Collection \\
\hline Ouchtata B & WT16 & Wild & Prospection Tunisia \\
\hline Lambrusque Cap Negre 1 & WT17 & Wild & Vassal Collection \\
\hline Balta 1 & WT18 & Wild & Prospection Tunisia \\
\hline Bellif B3 & WT19 & Wild & Prospection Tunisia \\
\hline Lambrusque Tabarka 3 & WT20 & Wild & Vassal Collection \\
\hline Feidja 3 & WT21 & Wild & Prospection Tunisia \\
\hline Bellif B2 & WT22 & Wild & Prospection Tunisia \\
\hline
\end{tabular}

Accurate identification of crop accessions is required for conservation and sustainable use of plant genetic resources (Arif et al., 2010). Among the most valuable horticultural crops in the world, is cited the species Vitis vinifera L. Two forms of this species still coexist in Eurasia and in North Africa; the cultivated form, V. vinifera subsp. vinifera (or sativa) and the wild form $V$. vinifera subsp. silvestris (or sylvestris) (This et al., 2006).

Identification of grapevine cultivars is complicated by the large number of varietal synonyms and homonyms, by the intensive exchange of plant material and by the presence of clonal diversity within each variety. Therefore testing easy and accurate cultivars identification molecular markers is a necessity to manage properly the rich variability of grapevine (Cabezas et al., 2011).

In spite of all the effort dedicated to SSR genotyping and standardization of allele sizes and genotypes (This et al., 2004), there are still frequent problems of allele identification among laboratories using different DNA fragment separation technologies. Moreover, SSR genotyping is difficult to multiplex (Lijavetzky et al., 2007).

Recently, the rapid application of partial or complete genome sequencing approaches is identifying different sets of nucleotide polymorphisms (SNP) that can be very useful for such purposes. Although SNP markers are bi-allelic, and therefore not as polymorphic as microsatellites, the high number of loci that can be multiplexed and the possibilities of automation as well as their highly repeatable results under any analytical procedure make them the future markers of choice for any type of genetic identification. Moreover, the more evolutionary conserved nature of SNPs makes them less subject to the problem of homoplasy (Brumfield et al., 2003; Cabezas et al., 2011).

In this study, we address the question of whether the detected set of SNP molecular markers is efficacy in cultivars identification and wild accessions discrimination for a representative sample of cultivated and wild grapevine accessions 


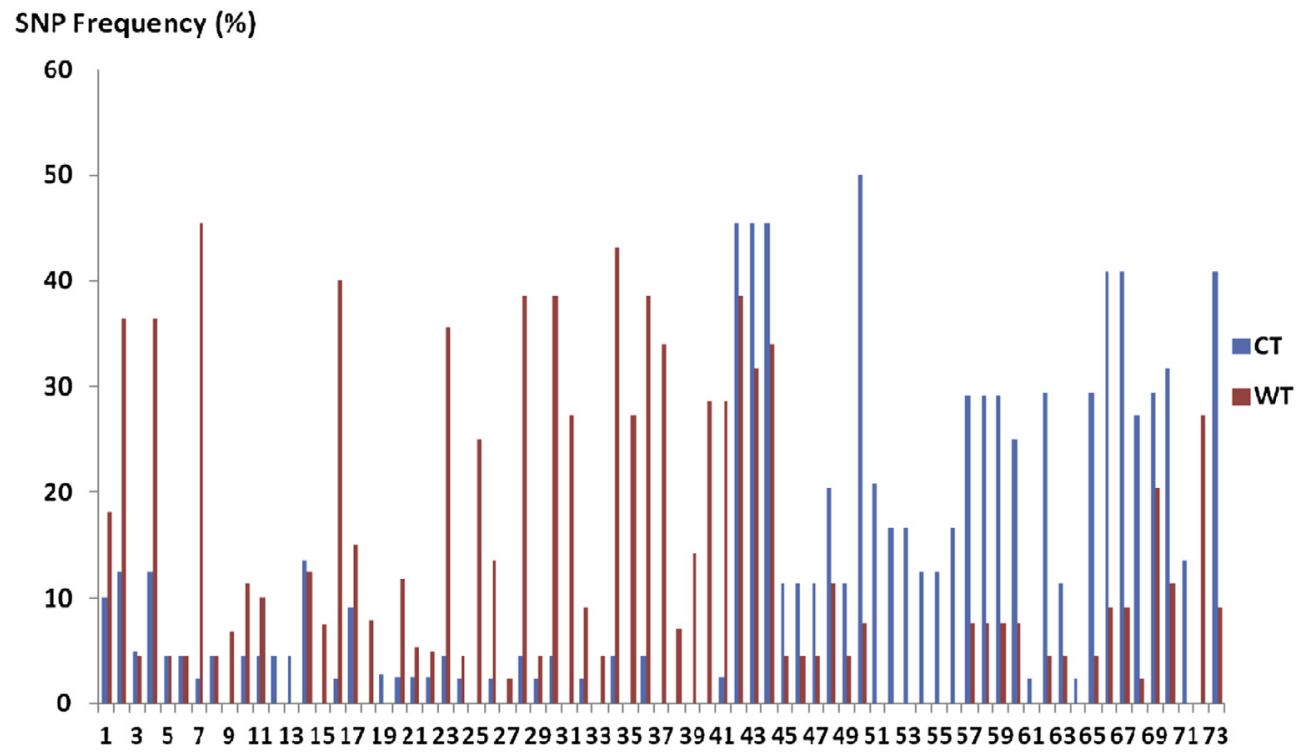

Fig. 1. Variations of SNP frequencies (\%) among the studied samples. CT: Tunisian cultivars, WT: Tunisian wild accessions.

traditionally grown in Tunisia. On the other hand we assessed genetic polymorphism and relationships between the studied samples based on the detected set of SNPs.

\section{Material and methods}

\subsection{Plant material}

This study is based on a representative sample of Tunisian grapevine accessions consisted of 22 autochthon cultivars and 22 indigenous native wild accessions. Characteristics of the studied samples are presented in Table 1. Among this sample Tunisian cultivars were from the Centre of Biotechnology Borj Cedria Collection (Tunisia), five Tunisian wild accession are sampled from the INRA Domaine de Vassal Grape Germplasm Repository (France, www.montpellier.inra.fr/vassal) and 17 wild accessions were prospected from Northwest part of Tunisia.

\subsection{Molecular analysis}

DNA was isolated from young leaves frozen in liquid nitrogen and ground in a mortar according to the protocol for DNeasy Plant Mini Kit (Qiagen, Hilden, Germany). SNP molecular markers were detected by direct sequencing of the 4 genes VvMYBA1, VvMYBA2, NAC4 and NCED1. PCR fragments were amplified, sequenced and analyzed as described by Le Cunff et al. (2008). Primers used in amplification and sequencing of the four gene fragments were listed in Fournier Level et al. (2010) and Riahi (2011).

\subsection{Data analysis}

SNPs were identified using the Staden Package (Bonfield et al., 1995) and coded according to international codes (CornishBowden, 1985). Haplotype reconstructions were carried out applying Phase software (Stephens and Scheet, 2005) using the SNiPlay web-based tool for SNP and polymorphism analysis (Dereeper et al., 2011). This SNiPlay web-based tool was used to

Table 2

Genetic diversity parameters for the studied samples. nSNP: number of SNPs, MNHs: mean number of haplotypes, Pi: nucleotide genetic diversity, Hd: haplotype genetic diversity. Genetic diversity parameters for the studied samples. nSNP: number of SNPs, MNHs: mean number of haplotypes, Pi: nucleotide genetic diversity, Hd: haplotype genetic diversity.

\begin{tabular}{llrll}
\hline & nSNP & MNHs & Mean Pi & Mean Hd \\
\hline Wild accessions & 61 & 10.25 & 0.00476 & 0.745 \\
Cultivars & 60 & 5.75 & 0.00329 & 0.480 \\
Total sample & 73 & 13.25 & 0.00486 & 0.689 \\
\hline
\end{tabular}




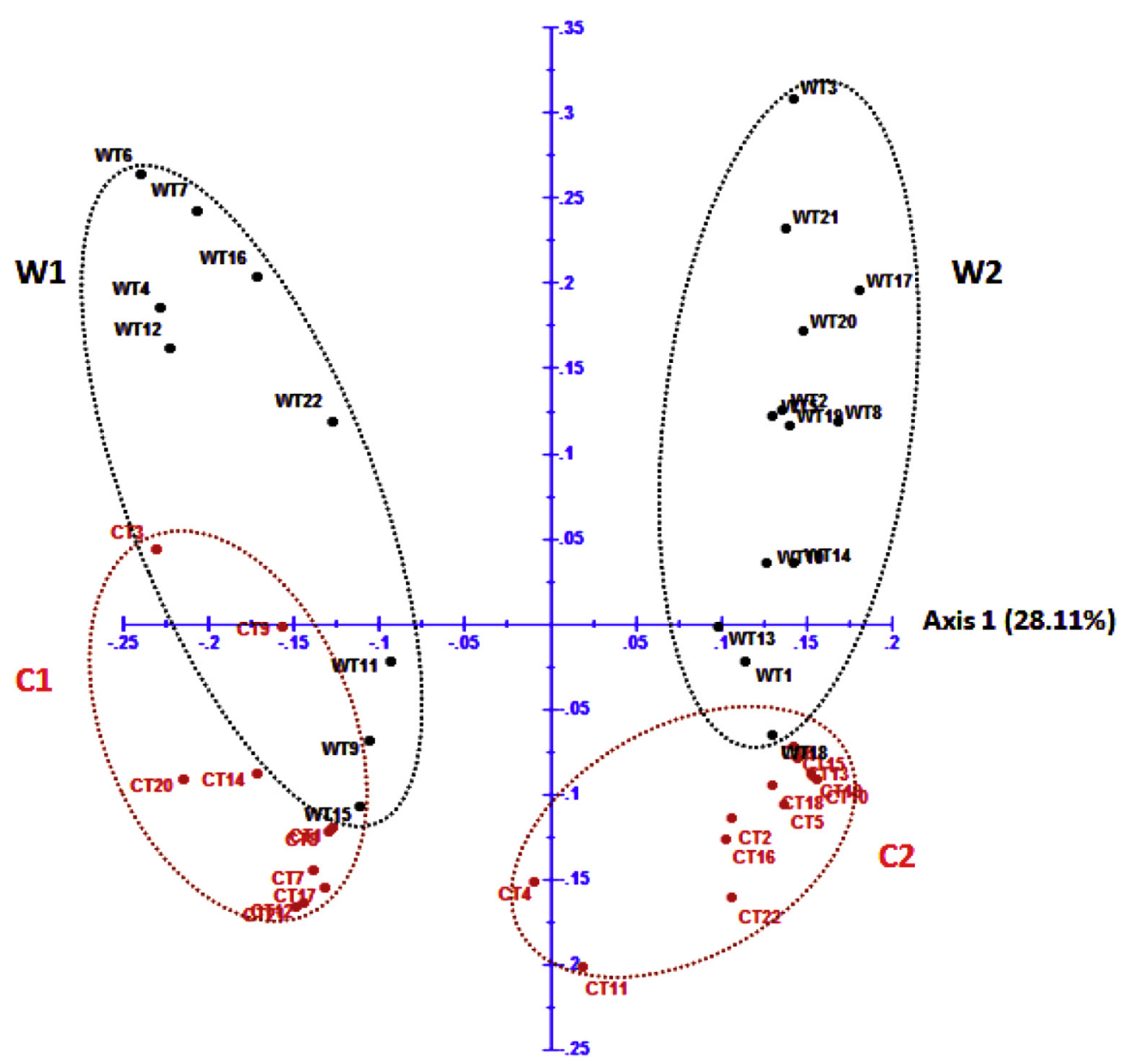

Axis $2(24.76 \%)$

Fig. 2. AFTD analysis based on genotypic data of 73 SNP loci. Red: Tunisian cultivars; black: Tunisian wild accessions. (For interpretation of the references to colour in this figure legend, the reader is referred to the web version of this article.)

achieve statistical analysis of SNP frequencies, mapping and annotation and polymorphism analysis. Haplotypic diversity (Hd) and nucleotidic diversity (Pi) and their error estimates were calculated for each gene pool using DnaSP 4.0 software (Rozas et al., 2003). Probabilities of identity PI for the studied loci (Paetkau et al., 1995) were calculated using IDENTITY 4.0 (Wagner and Sefc, 1999).

Dissimilarity from allelic data was calculated using the software DARwin v5 (Perrier et al., 2003) and used to perform AFTD analysis and Neighbor Joining Trees in order to visualize genetic relationships among the analyzed accessions. The significance of each node was evaluated by bootstrapping data for 1000 replications of the original matrix.

\section{Results and discussion}

\subsection{Molecular polymorphism of the studied samples}

The sequencing of $3.726 \mathrm{~kb}$ of grape DNA genome among 44 local Tunisian grapevine accessions has allowed the detection of 73 SNPs which gave an average of one SNP every $51 \mathrm{bp}$. According to our results SNP frequency vary between $1.1 \%$ and $46.6 \%$ for the total studied sample (Supplementary Table S1). An important variation of SNP frequencies is observed between wild and cultivated samples. SNP frequency varies from 0 to $50 \%$ for cultivated germplasm and from 0 to $45.5 \%$ for wild sample. Among the total detected SNPs, 48 SNPs are shared between cultivated and wild accessions, 12 SNPs are specific to cultivars and 13 SNPs are specific to wild accessions (Fig. 1). 


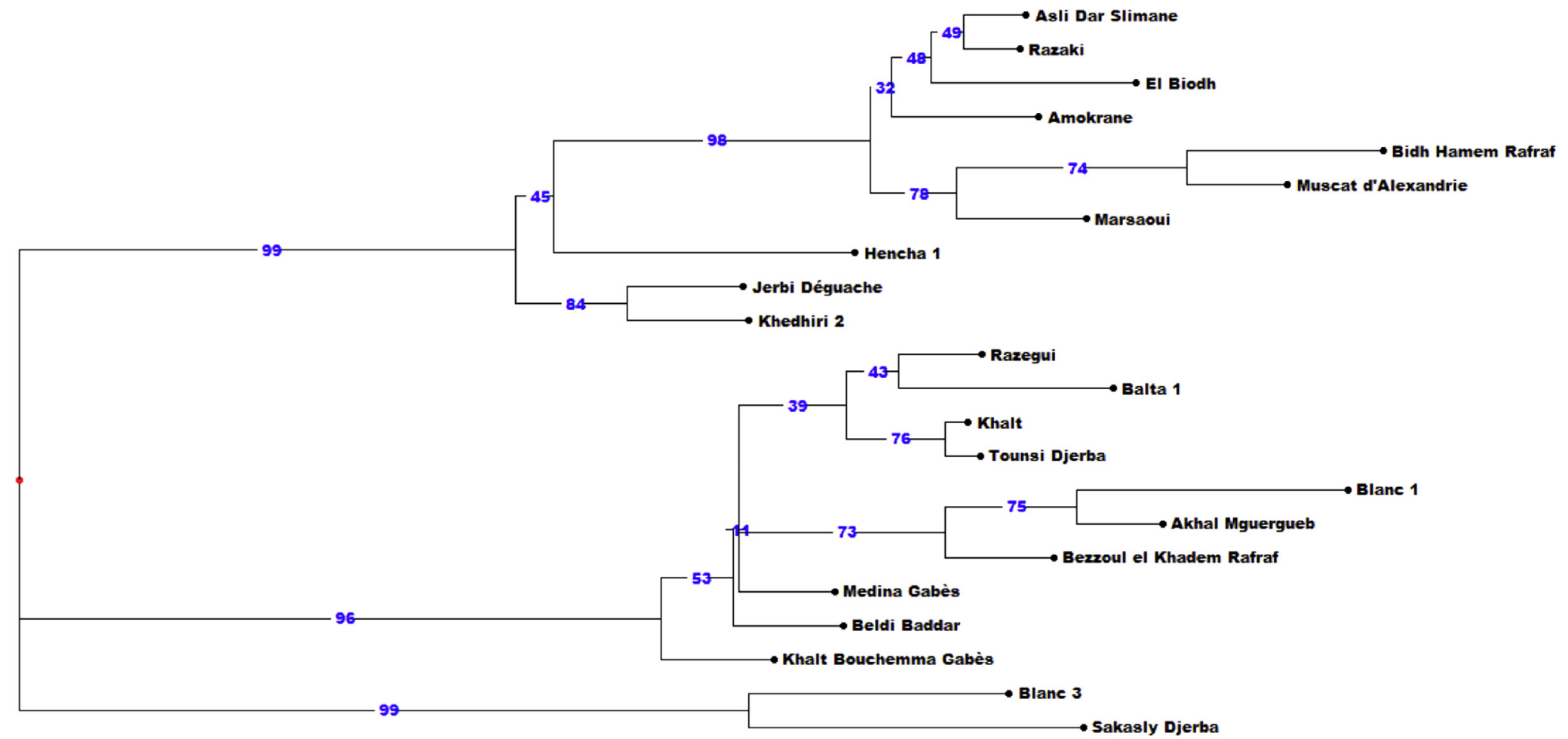

Fig. 3. Neighbor joining tree showing the discrimination of the studied cultivars based on 27 SNPs. 


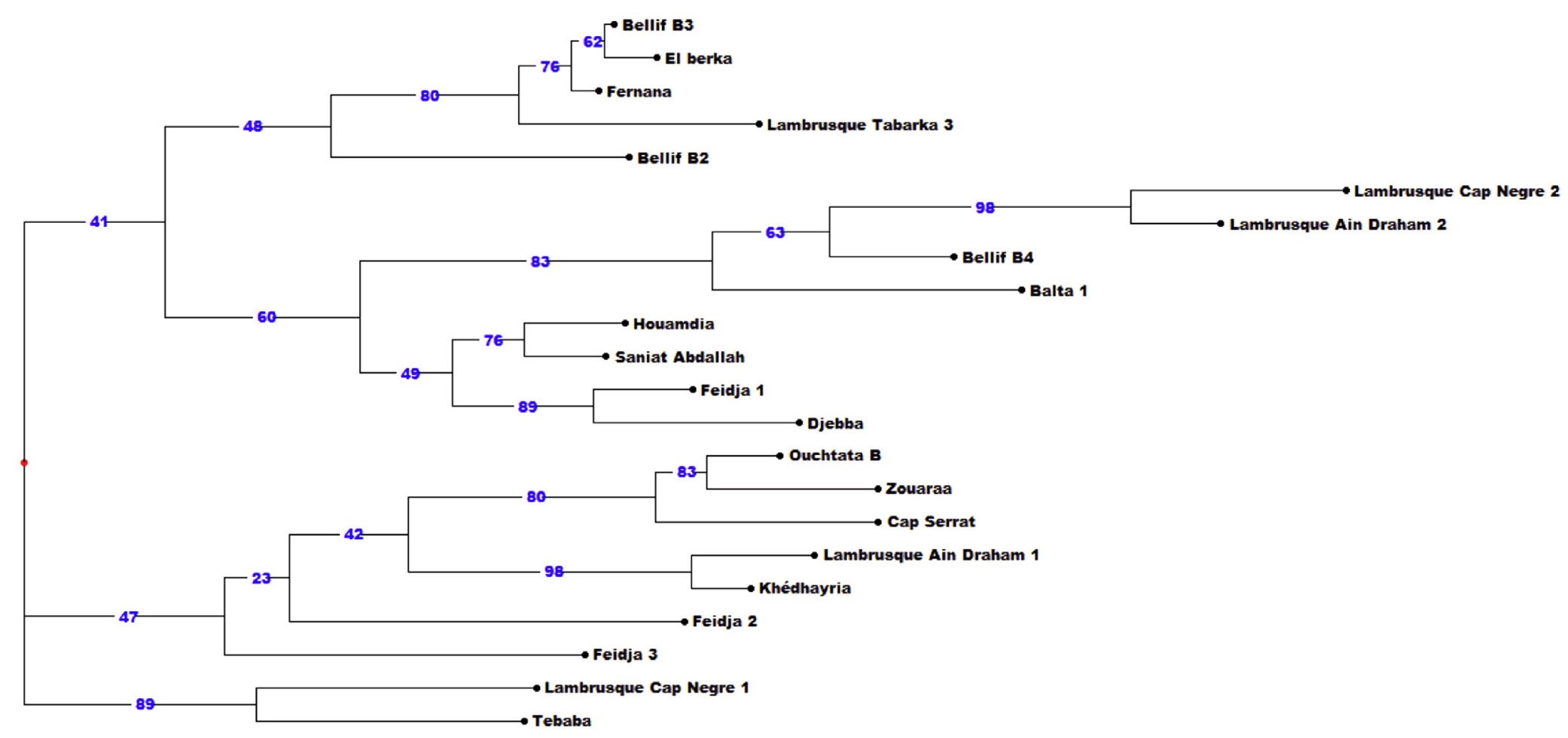


Expected heterozygosity He for the studied loci varies between 0.022 and 0.62 for the total sample. The sample of cultivars presents He values varying from 0.044 to 0.644 whereas wild accessions highlighted He levels ranging from 0.044 to 0.628 (Supplementary Table S1). As a molecular marker, the SNP expected heterozygosity is usually lower due to its bi-allelic nature. Our results are consistent with those of Cabezas et al. (2011) concerning the species Vitis vinifera L. who cited He values ranging from 0.107 to 0.501 for SNP markers.

Comparable levels were recorded in others studies concerning plant species. In Actinidia chinensis, the expected heterozygosities ranged from 0 to 0.500 for SNP molecular markers (Zhou et al., 2011). According to our results He values across all studied loci vary from 0.2847 (cultivars) to 0.3123 (wild sample). This level is lower than results of Cabezas et al. (2011) concerning the same species which cited a higher He value (0.404). Our results are higher than SNP expected heterozygosity in Eurycoma longifolia (0.216, Osman et al., 2003), maize (0.263, Ching et al., 2002) and Populus nigra (0.24, Kaya, 2013). However higher expected heterozygosity level (0.426) was observed in sunflower (Bachlava et al., 2012).

The observed heterozygosity in the studied sample varies from 0 to 0.59 . A variation of this parameter according to the studied sample was revealed. Thus, Ho values ranged from 0 to 0.545 in the sample of cultivars and from 0 to 0.636 for wild accessions. Our results are comparable to those by Cabezas et al. (2011) who cited Ho levels ranging from 0.060 to 0.765 for grapevine. This is comparable to results by Zhou et al. (2011) about the species Actinidia chinensis which showed observed heterozygosities ranging from 0 to 0.875 .

In this study, observed heterozygosities across all the studied loci range from 0.1873 (cultivars) to 0.2013 (wild accessions). This level is lower than what is reported for grapevine by Cabezas et al. (2011) who reported an observed heterozygosity average of 0.397 . This level is comparable to results for the species Eurycoma longifolia which present a Ho value of 0.182 (Osman et al., 2003). Higher levels of observed heterozygosity were cited of SNP markers in olive tree (Olea europaea L.) which vary between 0.292 and 0.708 (Rekik Hakim et al., 2010) and P. nigra (0.34) plant species (Kaya, 2013).

Important levels of genetic polymorphism are obtained for the studied sample. However, all genetic diversity parameters indicate the wild accessions (nSNP: 61, MNHs: 10.25 , Pi: $0.00476, \mathrm{Hd}: 0.745$ ) as more polymorphic than the sample of cultivars (nSNP: 60, MNHs: 5.75, Pi: 0.00329, Hd: 0.480), Table 2. This result is expected as wild genotypes generally showed more polymorphism than cultivated or elite genotypes (Russell et al., 2004). This may be due to the presence of unique alleles present in wild genotypes, which have been lost during the cultivation or adoption in case of cultivated and elite genotypes (Russell et al., 2004).

However, according to the largest analysis of genetic diversity in grape based on nuclear SSR molecular markers, $V$. vinifera subsp. sylvestris is less diverse than the domesticated forms, which could be due to the scarcity of the endangered wild form, small natural populations and the small number of samples available (Laucou et al., 2011). Our study confirms previous reports (Riahi et al., 2010, 2011, 2012) and highlights the utility of Tunisian wild germplasm as a reservoir of genetic polymorphism for exploiting its remarkable genetic diversity for grapevine improvement programs. It is necessary to preserve this phytogenetic resource to be used for breeding programs and to restore its destructed habitats by human different impacts.

\subsection{Genetic structure of the studied accessions}

In order to analyze genetic relationships between the studied accessions, an AFTD analysis was constructed based on the detected 73 SNPs. A genetic structure was observed among the studied accessions (Fig. 2). This analysis revealed a clear classification of the analyzed accessions according to their taxonomic status (wild, cultivated) based on the axis 1 . The axis 2 subdivides each sample of wild and cultivated sample in two groups, W1 and W2 for wild accessions and C1 and C2 for cultivated sample. A clear separation between domesticated and wild accessions is shown by this analysis. However, an overlap between the two groups is reported. Thus, we note the classification of the cultivars Balta 1 and Akhal Mguergueb with Tunisian wild accessions in group W1. Similarly, wild accessions Balta 1 have been classed with cultivars in group C2 and wild accessions Lambrusque Ain Draham 2 and Lambrusque Cap Negre 2 in the group of cultivars C1. This can be explained by the occurrence of outcrossing events between wild accessions and cultivated ones. These genetic relationships are likely responsible in a part of the important genetic diversity level recorded for Tunisian grapevine even cultivated or wild accessions.

These results highlight the efficiency of SNP molecular marker in genetic structure analysis. According to Osman et al. (2003), SNPs in Eurycoma longifolia reflects the geographic origins of individual plants and can distinguish different natural populations. Moreover, our results suggest two probable origins for Tunisian cultivars. According to molecular data the first origin of a part of Tunisian cultivars is attributed to the East region (Riahi et al., 2011, 2012). Indeed, viticulture was introduced in Tunisia by the Phoenicians, the founders of Carthage, who brought with them their taste for wine (Greene and Kehoe, 1991). The second origin of Tunisian cultivars may be West Europe region. During the settlement of Roman civilization in Tunisia, an import of European cultivars has been probably occurred. Moreover, an exchange of grapevine cultivars between North African region and Spain could be occurred.

\subsection{Discrimination potential of the studied SNPS}

The potential of the markers to yield different genotypes for as many cultivars as possible is of great interest, and selection of the most informative markers reduces the number of loci to be investigated for reliable cultivar distinction 
(Sefc et al., 2000). In order to characterize the most informative markers among the set of 73 SNP loci assayed we have calculated the probability of identical genotypes (PI) for each loci among the studied samples.

Probability to obtain identical genotypes (PI) for the investigated locus in the total sample ranged from 0.2240 (NCED-K11) to 0.9558 (MA2-R308). For cultivated sample the most informative SNP marker was NCED-K11 (PI = 0.1988) whereas the locus MA1-Y477, MA1-M231, MA2- M226, MA2-W379, MA2-K124, MA2-R366, NCED-M516, NCED-Y657 are the least informative ( $\mathrm{PI}=0.9141)$. Concerning wild accessions the locus MA2-K556 and MA2-S551 are the more discriminative $(P I=0.2153)$ while the locus MA2-R308 and NCED-Y949 have the lowest PI value (0.9141). Cumulative probability to obtain identical genotypes is $9.12 \times 10^{-22}$ based on the total sample, $7.909 \times 10^{-17}$ for cultivars, and $2.433 \times 10^{-18}$ for wild sample. Our findings are comparable to those of Cabezas et al. (2011) who cited PI value for SNP markers in grapevine ranging from 0.375 to 0.804 with a cumulative probability of identity of $1.4 \cdot 10^{-17}$ (Cabezas et al., 2011). This indicate that the whole SNP set used in our study has a very high discriminating capacity for the studied grapevine accession even cultivated or wild ones.

The set of 73 SNP molecular markers allowed the unambiguous discrimination of all the studied cultivars and wild accessions. Based on PI, He and Ho parameters, we aimed to choose the minimal SNP sets able to discriminate grapevine cultivars and wild accessions. Our analysis showed that a set of 27 SNPs molecular markers is required for the identification of Tunisian cultivars. However, a set of 22 SNPs is sufficient to discriminate the wild accessions. The lists of the two minimal sets of SNP molecular marker sufficient to discriminate Tunisian wild and cultivated accessions are showed in Supplementary Table S1. A phylogenetic trees constructed based on these two sets of SNP for cultivars and wild sample (Figs. 3 and 4 respectively) showed that the studied accessions were separated well and grouped differently in the entire dendrograms derived from the SNP data. To the best of our knowledge, this is the minimal set of SNPs able to identify and discriminate samples of grapevines cultivars and wild accessions which confirm the high efficiency and informativeness of the investigated SNPs.

These results confirm findings by Dong et al. (2010) and show that single nucleotide polymorphisms could be an efficient and powerful method for grapevine cultivar identification. In other studies an identification key was constructed indicating that five SNPs were adequate to discriminate nine out of the 10 varieties olive (Bazakos et al., 2012). The two SNP sets selected in this study could be taken into consideration in further studies interested to cultivars identification and wild accessions discrimination of the species Vitis vinifera $\mathrm{L}$.

\section{Acknowledgments}

The authors are grateful to INRA, Montpellier France, and to the Tunisian Ministry of Higher Education, Scientific Research and Technology for financial support.

\section{Appendix A. Supplementary data}

Supplementary data related to this article can be found at http://dx.doi.org/10.1016/j.bse.2013.08.021.

\section{References}

Arif, I.A., Bakir, M.A., Khan, H.A., Al Farhan, A.H., Al Homaidan, A.A., Bahkali, A.H., Al Sadoon, M., Shobrak, M., 2010. A brief review of molecular techniques to assess plant diversity. Int. J. Mol. Sci. 11, 2079-2096.

Bachlava, E., Taylor, C.A., Tang, S., Bowers, J.E., Mandel, J.R., et al., 2012. SNP discovery and development of a high-density genotyping array for sunflower. PLoS ONE 7 (1), e29814.

Barchi, L., Lanteri, S., Portis, E., Acquadro, A., Valè, G., Toppino, L., Rotino, G.L., 2011. Identification of SNP and SSR markers in eggplant using RAD tag sequencing. BMC Genomics 12, 304.

Bazakos, C., Dulger, A.O., Uncu, A.T., Spaniolas, S., Spano, T., Kalaitzis, P., 2012. A SNP based PCR-RFLP capillary electrophoresis analysis for the identification of the varietal origin of olive oils. Food Chem. 134, 2411-2418.

Bonfield, J.K., Smith, K.F., Staden, R., 1995. A new DNA sequence assembly program. Nucleic Acids Res. 23, $4992-4999$.

Brumfield, R.T., Beerli, P., Nickerson, D.A., Edwards, S.V., 2003. The utility of single nucleotide polymorphisms in inferences of population history. Trends Ecol. Evol. (Amst.) 18, 249-256.

Cabezas, J.A., Ibanez, J., Lijavetzky, D., Velez, D., Bravo, G., Rodriguez, V., Carreno, I., Jermakow, A.M., Carreno, J., Ruiz-Garcia, L., Thomas, M.R., MartinezZapater, J.M., 2011. A 48 SNP set for grapevine cultivar identification. BMC Plant. Biol. 11, 153.

Ching, A., Caldwell, K.S., Jung, M., Dolan, M., Smith, O.S., Tingey, S., Morgante, M., Rafalski, A.J., 2002. SNP frequency, haplotype structure and linkage disequilibrium in elite maize inbred lines. BMC Genet. 3, 19.

Cornish-Bowden, A., 1985. Nomenclature for incompletely specified bases in nucleic acid sequences: recommendations. Nucleic Acids Res. 13, 3021-3030.

Dereeper, A., Nicolas, S., Le Cunff, L., Bacilieri, R., Doligez, A., Peros, J.P., Ruiz, M., This, P., 2011. SNiPlay: a web-based tool for detection, management and analysis of SNPs. Application to grapevine diversity projects. BMC Bioinformatics 12, 134.

Dong, Q.H., Cao, X., Yang, G., Yu, H.P., Nicholas, K.K., Wang, C., Fang, J.G., 2010. Discovery and characterization of SNPs in Vitis vinifera and genetic assessment of some grapevine cultivars. Sci. Hortic. 125, 233-238.

Fournier-Level, A., Lacombe, T., Le Cunff, L., Boursiquot, J.M., This, P., 2010. Evolution of the VvMybA gene family the major determinant of berry colour in cultivated grapevine (Vitis vinifera L.). Heredity 104, 351-362.

Ganal, M.W., Altmann, T., Röder, M.S., 2009. SNP identification in crop plants. Curr. Opin. Plant. Biol. 12, $211-217$.

Ganopoulos, I., Tsaballa, A., Xanthopoulou, A., Madesis, P., Tsaftaris, A., 2013. Sweet Cherry Cultivar Identification by High-Resolution-Melting (HRM) Analysis Using Gene-Based SNP Markers. Plant Mol. Biol. Rep. 31, 763-768.

Greene, J.A., Kehoe, D.P., 1991. Mago the Carthaginian on agriculture: archeology and the ancient sources. In: Proceedings of the "Congrès international des études phéniciennes et puniques", Tunis, Tunisia, pp. 11-16.

Jiang, D., Ye, Q.L., Wang, F.S., Cao, L., 2010. The mining of citrus EST-SNP and its application in cultivar discrimination. Agr. Sci. China 9 (2), 179-190.

Kaya, Z., 2013. SNP diversity of candidate genes encoding cellulose and lignin biosynthetic enzymes in Populus nigra clone bank in Turkey: its implications for conservation and breeding. In: International Plant \& Animal Genome XXI/January 12-16, San Diego, CA, USA. 
Laucou, V., Lacombe, T., Dechesne, F., Siret, R., Bruno, J.P., Dessup, M., Dessup, T., Ortigosa, P., Parra, P., Roux, C., Santoni, S., Vares, D., Peros, J.P., Boursiquot, J.M., This, P., 2011. High throughput analysis of grape genetic diversity as a tool for germplasm collection management. Theor. Appl. Genet. $122,1233-1245$.

Le Cunff, L., Fournier-Level, A., Laucou, V., Vezzulli, S., Lacombe, T., Adam-Blondon, A.F., Boursiquot, J.M., This, P., 2008. Construction of nested genetic core collections to optimize the exploitation of natural diversity in Vitis vinifera L. subsp. sativa. BMC Plant. Biol. 8, 31.

Lijavetzky, D., Cabezas, J.A., Ibánez, A., Rodríguez, V., Martínez-Zapater, J.M., 2007. High throughput SNP discovery and genotyping in grapevine (Vitis vinifera L.) by combining a re sequencing approach and SNPlex technology. BMC Genomics. 8, 424.

Osman, A., Jordan, B., Lessard, P.A., Muhammad, N., Haron, M.R., Riffin, N.M., Sinskey, A.J., Rha, C.K., Housman, D.E., 2003. Genetic diversity of Eurycoma longifolia inferred from single nucleotide polymorphisms. Plant Physiol. 131 (3), 1294-1301.

Paetkau, D., Calvert, W., Stirling, I., Strobeck, C., 1995. Microsatellite analysis of population structure in Canadian polar bears. Mol. Ecol. 4, 347-358.

Perrier, X., Flori, A., Bonnot, F., 2003. Data 362 analysis methods. In: Hamon, P., Seguin, M., Perrier, X., Glaszmann, J.C. (Eds.), Genetic Diversity of Cultivated Tropical Plants. Science Publishers, Montpellier.

Primmer, C.R., Borge, T., Lindell, J., Saetre, G.P., 2002. Single nucleotide polymorphism characterization in species with limited available sequence information: high nucleotide diversity revealed in the avian genome. Mol. Ecol. 11 (3), 603-612.

Rafalski, A., 2002. Applications of single nucleotide polymorphisms in crop genetics. Curr. Opin. Plant. Biol. 5, 94-100.

Reale, S., Doveri, S., Diaz, A., Angiolillo, A., Lucentini, L., Pilla, F., Martin, A., Donini, P., Lee, D., 2006. SNP-based markers for discriminating olive (Olea europaea L.) cultivars. Genome 49, 1193-1205.

Rekik Hakim, I., Grati Kammoun, N., Makhloufi, E., Rebaï, A., 2010. Discovery and potential of SNP markers in characterization of Tunisian olive germplasm. Diversity 2, 17-27.

Riahi, L., Zoghlami, N., El-Heit, K., Laucou, V., Le Cunff, L., Boursiquot, J.M., Lacombe, T., Mliki, A., Ghorbel, A., This, P., 2010. Genetic structure and differentiation among grapevines (Vitis vinifera) accessions from Maghreb region. Genet. Resour. Crop Evol. 57, $255-272$.

Riahi, L., 2011. Caractérisation des ressources génétiques de la vigne Vitis vinifera L. par différents marqueurs moléculaires (Ph.D. thesis). Facultés des Sciences de Tunis.

Riahi, L., Zoghlami, N., Laucou, V., Mliki, A., This, P., 2011. Use of chloroplast microsatellite markers as a tool to elucidate polymorphism, classification and origin of Tunisian grapevines. Sci. Hortic. 130, 781-786.

Riahi, L., Laucou, V., Le Cunff, L., Zoghlami, N., Boursiquot, J.M., Lacombe, T., El-Heit, K., Mliki, A., This, P., 2012. Highly polymorphic nSSR markers: a useful tool to assess origin of North African cultivars and to provide additional proofs of secondary grapevine domestication events. Sci. Hortic. 141, 53-60.

Rozas, J., Sanchez-DelBarrio, J.C., Messeguer, X., Rozas, R., 2003. DnaSP, DNA polymorphism analyses by the coalescent and other methods. Bioinformatics 19, 2496-2497.

Russell, J., Booth, A., Fuller, J., Harrower, B., Hedley, P., Machray, G., Powell, W., 2004. A comparison of sequence-based polymorphism and haplotype content in transcribed and anonymous regions of the barley. Genome 47, 389-398.

Stephens, M., Scheet, P., 2005. Accounting for decay of linkage disequilibrium in haplotype inference and missing-data imputation. Am. J. Hum. Genet. 76 (3), 449-462.

Sefc, K.M., Lopes, M.S., Lefort, F., Botta, R., Roubelakis-Angelakis, K.A., Ibáñez, J., Pejic, I., Wagner, H.W., Glössl, J., Steinkellner, H., 2000. Microsatellite variability in grapevine cultivars from different European regions and evaluation of assignment testing to assess the geographic origin of cultivars. Theor. Appl. Genet. 100, 498-505.

Shirasawa, K., Shiokai, S., Yamaguchi, M., Kishitani, S., Nishio, T., 2006. Dot-blot-SNP analysis for practical plant breeding and cultivar identification in rice. Theor. Appl. Genet. 113, 147-155.

This, P., Jung, A., Boccacci, P., Borrego, J., Botta, R., Costantini, L., Crespan, M., Dangl, G.S., Eisenheld, C., Ferreira-Monteiro, F., Grando, M.S., Ibanez, J., Lacombe, T., Laucou, V., Magalhaes, R., Meredith, C.P., Milani, N., Peterlunger, E., Regner, F., Zulini, L., Maul, E., 2004. Development of a standard set of microsatellite reference alleles for identification of grape cultivars. Theor. Appl. Genet. 109, 1448-1458.

This, P., Lacombe, T., Thomas, M.R., 2006. Historical origins and genetic diversity of wine grapes. Trends Genet. 22, 511-519.

Wagner, H.W., Sefc, K.M., 1999. IDENTITY 4.0. Centre for Applied Genetics. University of Agricultural Sciences, Vienna.

Zhou, J., Liu, Y., Huang, H., 2011. Characterization of 15 novel single nucleotide polymorphisms (SNPs) in the Actinidia chinensis species complex (Actinidiaceae). Am. J. Bot., 100-102. 